\title{
Morphogenesis of Kidney in Crossbred Pig (Sus scrofa) Foetii
}

\author{
Morfogénesis del Riñón en Fetos de Cerdos Híbridos (Sus scrofa) \\ Kamal Sarma \& Bilal Ahmed
}

SARMA, K. \& AHMED, B. Morphogenesis of kidney in crossbred pig (Sus scrofa) foetii. Int. J. Morphol., 25(1):129-132, 2007.

SUMMARY: Twenty five numbers of crossbred pig foetii were selected based on their crown-rump length and subsequently divided into 5 age groups consisting of 5 animals in each group viz. group I (41-55 days), group II (56-70 days), group III (71-85 days), group IV (86-100 days) and groupV (101-114 days). No renal pelvis was evident in group I in all the kidneys under study. From group II onwards, the renal pelvis was distinct and extensive with a well developed ureter that originated from the middle of the pelvis in both the kidneys.

KEY WORDS: Crossbred pig ; Kidney; Ontogeny.

\section{INTRODUCTION}

The anatomical details of the kidney of domestic animals (Sisson, 1975) One Horned Rhinoceros (Talukdar et al., 2003 and biometrical study of the kidney of buffalo (Malik et al., 1978) were reported. The morphometry and detailed sequential changes involved in the development of the kidney in crossbred pig is meager. Hence, the present study was conducted to elucidate the morphogenesis of kidneys in crossbred pig foetii.

\section{MATERIAL AND METHOD}

Crossbred pig foetii collected from abattoir comprised the experimental animals. Among these foetii, 25 numbers were selected based on their crown rump length and subsequently divided into 5 age groups consisting of 5 animals in each group viz. group I (41-55 days), group II (56-70 days), group III (71-85 days), group IV (86-100 days) and group IV (101-114 days). These foetii were fixed in $10 \%$ formaline solution. The kidneys from these animals were collected by abdomino-sternal approach and were refixed in $10 \%$ buffered formaline solution, for 48 hours. Then the biometrical parameters of the kidneys were recorded. The greatest length, width and thickness of the kidneys were measured by digital Vernier Calipers, separately for right and left kidneys. Then the kidneys were bisected longitudinally to expose the inner structures. Subsequently, the thickness of cortex and medulla were estimated with the help of digital Vernier Calipers. The data obtained were subjected to statistical analysis (Snedecor \& Cochran, 1967).

\section{RESULTS AND DISCUSSION}

Both the kidneys were irregularly elongated and deep grey in colour in all the age groups under study. The kidneys were attaching the posterior extremity of the adrenal gland at the respective sides. The kidneys in all cases were found below the lumber transverse processes, except the animals of group IV and V, where the kidney were detected more cranially. Malik \& Vais (1998) also reported that the right and left kidneys shifted rostrad with the advancement of age in goat. This cranial positioning of the kidneys might be due to relative variation in growth of different organs in the abdominal and pelvic cavities during various phases of embryonic development. No renal pelvis was evident in group I in all the kidneys under study. However, from group II onwards, the renal pelvis was distinct and extensive with a well developed ureter that originated from the middle of the pelvis in both the kidneys. This confirms the development of renal pelvis and ureter in early phase of the gestation period in pigs. In the foetii of group III onwards, the cortex was observed gradually becoming larger than the medulla. The pelvis became well demarcated from the medulla with a sharp demarcating line in group $\mathrm{V}$. 
SARMA, K. \& AHMED, B.

Table I. The mean, S. E. and range of biometrical parameters of the 25 right kidney of crossbred pig foetii

\begin{tabular}{|c|c|c|c|c|c|c|c|c|c|c|c|c|c|c|c|}
\hline \multirow[t]{2}{*}{ Group } & \multicolumn{3}{|c|}{ Length $(\mathrm{cm})$} & \multicolumn{3}{|c|}{ Width $(\mathrm{cm})$} & \multicolumn{3}{|c|}{ Thickness (cm) } & \multicolumn{3}{|c|}{ Thickness of cortex $(\mathrm{cm})$} & \multicolumn{3}{|c|}{ Thickness of medulla $(\mathrm{cm})$} \\
\hline & Mean & S.E. & Range & Mean & S.E. & Range & Mean & S.E. & Range & Mean & S.E. & Range & Mean & S.E. & Range \\
\hline I & 1.162 & 0.019 & $1.09-1.20$ & 0.840 & 0.088 & $0.68-1.10$ & 0.534 & 0.045 & $0.45-0.62$ & - & - & - & - & - & - \\
\hline II & 2.008 & 0.019 & $1.96-2.07$ & 0.946 & 0.019 & $0.90-1.00$ & 0.874 & 0.031 & $0.79-0.90$ & 0.230 & 0.018 & $0.19-0.29$ & 0.234 & 0.014 & $0.20-0.26$ \\
\hline III & 2.338 & 0.013 & $2.30-2.37$ & 1.238 & 0.007 & $1.22-1.26$ & 0.876 & 0.016 & $0.83-0.92$ & 0.239 & 0.009 & $0.21-0.27$ & 0.236 & 0.011 & $0.19-0.29$ \\
\hline IV & 2.442 & 0.013 & $2.4-2.47$ & 1.408 & 0.007 & $1.39-1.43$ & 0.970 & 0.012 & $0.93-1.00$ & 0.262 & 0.012 & $0.022-0.29$ & 0.242 & 0.009 & $0.22-0.29$ \\
\hline V & 2.470 & 0.020 & $2.40-2.52$ & 1.488 & 0.009 & $1.46-1.51$ & 0.990 & 0.011 & $0.96-1.02$ & 0.280 & 0.009 & $0.25-0.30$ & 0.264 & 0.014 & $0.22-0.30$ \\
\hline
\end{tabular}

Table II. The mean, S.E. and range of biometrical parameters of the 25 left kidney of crossbred pig foetii.

\begin{tabular}{|c|c|c|c|c|c|c|c|c|c|c|c|c|c|c|c|}
\hline \multirow[t]{2}{*}{ Group } & \multicolumn{3}{|c|}{ Length $(\mathrm{cm})$} & \multicolumn{3}{|c|}{ Width $(\mathrm{cm})$} & \multicolumn{3}{|c|}{ Thickness (cm) } & \multicolumn{3}{|c|}{ Thickness of cortex $(\mathrm{cm})$} & \multicolumn{3}{|c|}{ Thickness of medulla $(\mathrm{cm})$} \\
\hline & Mean & S.E. & Range & Mean & S.E. & Range & Mean & S.E. & Range & Mean & S.E. & Range & Mean & S.E. & Range \\
\hline I & 0.872 & 0.025 & $0.78-0.92$ & 0.608 & 0.011 & $0.58-0.64$ & 0.454 & 0.015 & $0.41-0.50$ & - & - & - & - & - & - \\
\hline II & 1.92 & 0.37 & $1.82-2.01$ & 1.142 & 0.023 & $1.09-1.20$ & 0.850 & 0.016 & $0.82-0.91$ & 0.234 & 0.010 & $0.21-0.26$ & 0.224 & 0.005 & $0.21-0.24$ \\
\hline III & 2.356 & 0.013 & $2.31-2.39$ & 1.284 & 0.016 & $1.23-1.31$ & 0.865 & 0.016 & $0.82-0.90$ & 0.240 & 0.010 & $0.21-0.29$ & 0.227 & 0.005 & $0.21-0.25$ \\
\hline IV & 2.380 & 0.037 & $2.30-2.51$ & 1.358 & 0.021 & $1.30-1.41$ & 0.950 & 0.016 & $0.91-1.00$ & 0.268 & 0.010 & $0.23-0.29$ & 0.240 & 0.010 & $0.21-0.27$ \\
\hline V & 2.604 & 0.014 & $2.56-2.64$ & 1.552 & 0.017 & $1.50-1.60$ & 1.062 & 0.018 & $1.00-1.10$ & 0.342 & 0.017 & $0.30-0.35$ & 0.304 & 0.013 & $0.27-0.35$ \\
\hline
\end{tabular}

Table III. Comparison of the measurements of biometrical parameters between the right and left kidneys in different age groups of crossbred pig foetii.

\begin{tabular}{|c|c|c|c|c|c|c|c|c|c|c|c|}
\hline \multirow[t]{3}{*}{$\mathrm{Sl} \mathrm{N}^{\circ}$} & \multirow[t]{3}{*}{ Group } & \multicolumn{2}{|c|}{ Length } & \multicolumn{2}{|c|}{ Width } & \multicolumn{2}{|c|}{ Thickness } & \multicolumn{2}{|c|}{$\begin{array}{l}\text { Thickness of } \\
\text { cortex }\end{array}$} & \multicolumn{2}{|c|}{$\begin{array}{c}\text { Thickness of } \\
\text { medulla }\end{array}$} \\
\hline & & "P" & "t" & "P" & "t" & "P" & "t" & "P" & "t" & "P" & "t" \\
\hline & & Value & Value & Value & Value & Value & Value & Value & Value & Value & Value \\
\hline 1 & I & $0.000^{\text {*ik }}$ & 9.23 & $0.058^{\mathrm{NS}}$ & 2.63 & 0.17 & 1.67 & - & - & - & - \\
\hline 2 & II & $0.080 \mathrm{NS}$ & 2.11 & $0.00^{* *}$ & -6.68 & $0.71^{\mathrm{NS}}$ & 0.40 & $0.85^{\mathrm{NS}}$ & -0.19 & $0.55^{\mathrm{NS}}$ & 0.66 \\
\hline 3 & III & $0.36^{\mathrm{NS}}$ & -0.98 & $0.045^{*}$ & -2.66 & $0.44^{\mathrm{NS}}$ & 0.81 & $0.68^{\mathrm{NS}}$ & 0.43 & $0.75^{\mathrm{NS}}$ & 0.34 \\
\hline 4 & IV & $0.26^{\mathrm{NS}}$ & 1.24 & $0.082^{\mathrm{NS}}$ & 2.31 & $0.35^{\mathrm{NS}}$ & 1.00 & $0.72^{\mathrm{NS}}$ & -0.37 & $0.75^{\mathrm{NS}}$ & 0.34 \\
\hline 5 & V & $0.002^{* *}$ & -5.44 & $0.021^{*}$ & -3.34 & $0.014^{*}$ & -3.42 & $0.017^{*}$ & -3.25 & 0.080 & -2.05 \\
\hline
\end{tabular}


Table IV. Percentage of increase in growth in terms of various biometrical parameters of the kidneys of crossbred pig foetii.

\begin{tabular}{|c|c|c|c|c|c|c|c|c|c|c|}
\hline \multirow[t]{2}{*}{ Groups } & \multicolumn{5}{|c|}{ Right kidney } & \multicolumn{5}{|c|}{ Left kidney } \\
\hline & Length & Width & Thickness & $\begin{array}{c}\text { Thickness of } \\
\text { cortex }\end{array}$ & $\begin{array}{l}\text { Thickness } \\
\text { of medulla }\end{array}$ & Length & Width & Thickness & $\begin{array}{c}\text { Thickness of } \\
\text { Cortex }\end{array}$ & $\begin{array}{l}\text { Thickness } \\
\text { of medulla }\end{array}$ \\
\hline Between I \& II & 84.6 & 10.6 & 34.0 & - & - & 104.8 & 53.4 & 40.6 & - & - \\
\hline Between II \& III & 33.0 & 29.2 & 0.2 & 0.8 & 0.5 & 43.6 & 14.2 & 1.5 & 0.6 & 0.3 \\
\hline Between III \& IV & 10.4 & 17.0 & 9.4 & 2.4 & 0.3 & 2.4 & 7.4 & 8.5 & 2.8 & 1.3 \\
\hline Between IV \& V & 2.8 & 8.0 & 2.0 & 1.8 & 2.2 & 22.4 & 19.4 & 11.2 & 7.4 & 6.4 \\
\hline
\end{tabular}

Fig. 1. Percentage of increase in growth in terms of various biometrical parameters of the kidneys of crossbred pig foetii.

\section{Right Kidney}

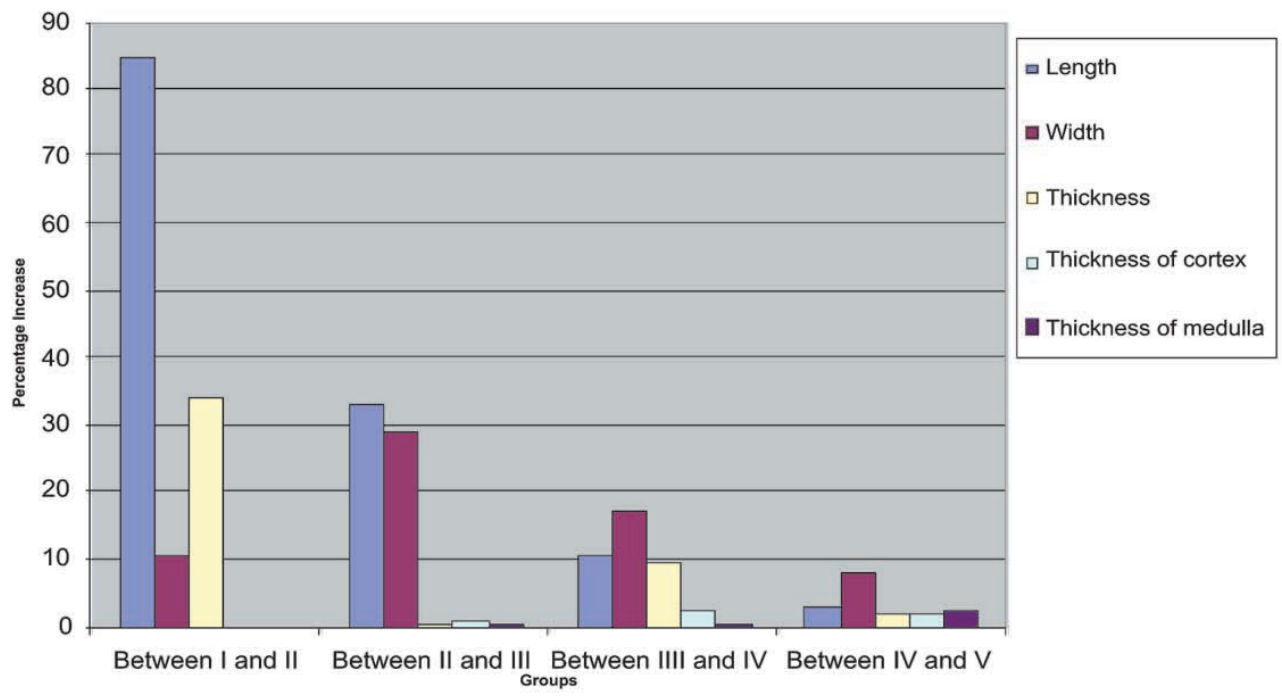

Left Kidney

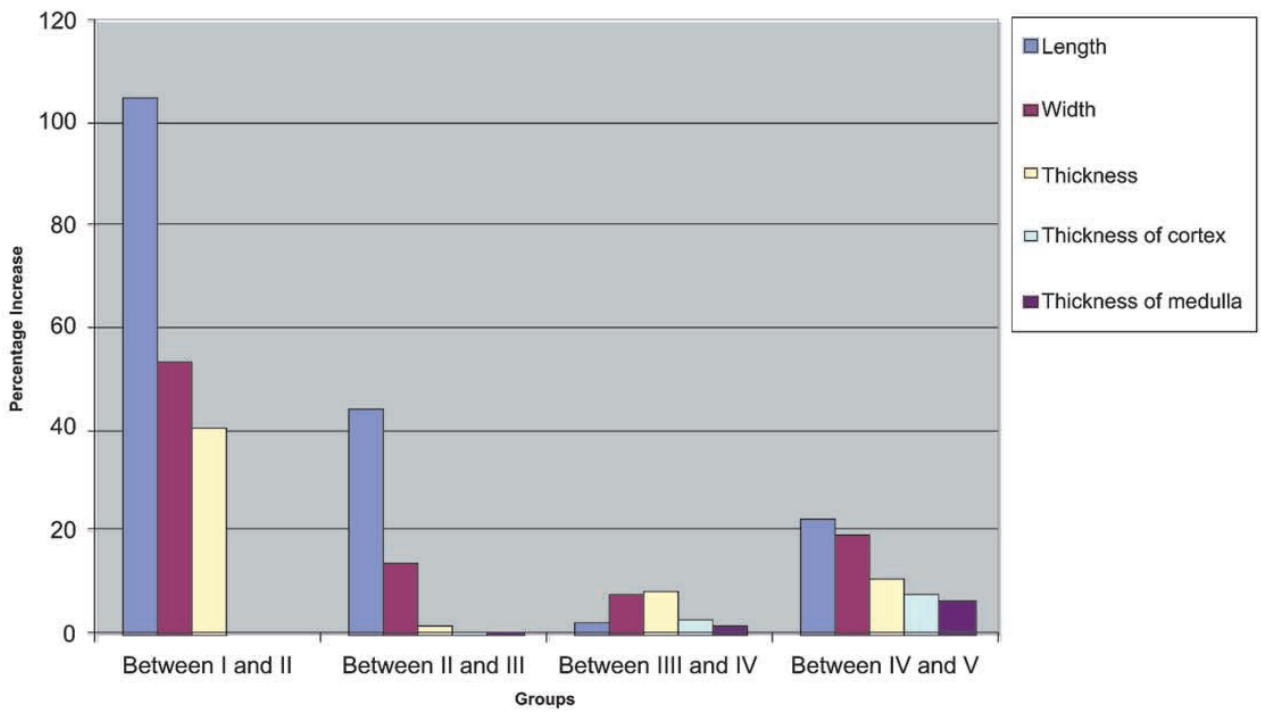

Various biometrical parameters pertaining to right and left kidneys of different age groups have been depicted in Table I.

The measurements of all the parameters varied between the right and left kidneys (Table II). The length of the right kidney was found having higher values than its left counterpart in rest age groups except group III and V. However, the values pertaining to width of the right kidney were more than the left one in group I and IV. Also the thickness of the right kidney were recorded more than those of the left kidney in all the age groups except in group V. The thickness of the cortical area in all the age groups in right kidney were lesser than those recorded in the left kidney. The left kidney exhibited higher values than its right counterpart in the measurements of thickness of medulla in all the age groups. 
Statistical analysis revealed that, the variation in growth between the left and right kidneys in terms of length in group I and V were highly significant $(p<0.01)$, however, no significant difference was noticed for the same in other age groups. The width of both the kidneys varied significantly $(p<0.05)$ in group III and V and this variation was highly significant in group II $(p<0.01)$. Significant variation $(p<0.05)$ between the right and left kidney was recorded in terms of thickness and thickness of cortex in group V.

However, no significant variation in the measurements of thickness of medulla was evident between right and left kidneys in all the age groups, indicating negligible bilateral variation in this aspect between both the kidneys during foetal growth. In the present study, maximum growth in length was observed in between group I and II in right $(84.6 \%)$ and left (104.8\%) kidneys, respectively, the growth being more in the left one. However, the increase in percentage of growth in width of the right kidney were observed in between groups II and III (29.2\%) and IV and V (8\%), respectively, while the same were recorded to be in balance between I and II (53.4\%) and III and IV (7.4\%), respectively, in case of left kidney. Similarly highest and least percentage of growth in thickness were documented in between group I and II and II and III, respectively, in both the kidneys. But no such trend was seen in thickness of cortex and medulla of the kidneys. The least growth in length was seen in between group IV and $\mathrm{V}$ in right kidney $(2.8 \%)$ and III and IV in left kidney (2.4\%), respectively, indicating a greater embryogenesis of both the kidneys in the early stages of development in crossbred pigs. Similar findings were also reported in foetal goats (Malik \& Vais). Similar patterns of embryonic growth was recorded in cerebral ventricles (Malik et. al., 1992 ) and scrotum (Malik et.al., 1995) in foetal goats.

The variation in growth among the various groups pertaining to embryonic life of the right kidney in terms of length, width and thickness was highly significant $(p<0.01)$, while the same pertaining to thickness of cortex and medulla was nonsignificant. In contrast, all the parameters of the left kidney under study showed highly significant $(p<0.01)$ variation among groups I to $\mathrm{V}$, indicative of better sequence of growth phase in the left kidney as compared to the right one. This trend of growth was accordance with the findings of Patten \& Carlson (1977), who reported that variable growth and structural diversities at different stages of development of an organ is a normal phenomena for accommodating and molding of the organ.

SARMA, K. \& AHMED, B. Morfogénesis del riñón en fetos de cerdos híbridos (Sus scrofa). Int. J. Morphol., 25(1):129-132, 2007.

RESUMEN: Se selecionaron 25 fetos de cerdos híbridos basándose en la longitud céfalocaudal y luego fueron separados en 5 grupos etarios de 5 animales cada uno: Grupo I (41-55 días), grupo II (56-70 días), grupo III (71-85 días), grupo IV (86-100 días) y grupo V (101-114 días). No se encontraron pelvis renales en el grupo I, en ninguno de los riñones en estudio. Desde el grupo II en adelante, la pelvis renal era claramente visible y grande, con un uréter bien desarrollado, que se originaba desde el centro de la pelvis, en ambos riñones.

PALABRAS CLAVE: Cerdo híbrido; Riñón; Ontogenia.

\section{REFERENCES}

Malik, M. R. ; Tiwari, G. P.\& Singh, A. P. The biometry of the kidney of buffalo (Bubalus bubalis). J. of Anatomical Society of India 27:11-4, 1978.

Malik, M. R.; Taluja, J. S. \& Parmar, M. L. Histogenesis and mode of growth of choroids plexus in goat fetuses. Indian J. of Animal Sciences, 62(12):1157-9, 1992.

Malik, M. R.; Taluja, J. S. \& Parmar, M. L. Histogenesis and mode of growth of scrotum in foetal goat. Indian J. of Animal Sciences, 65(4):409-13, 1995.

Malik, M. R. \& Vais, Rakhi. Morphogenesis of kidney in goat (Capra hircus). Indian J. of Veterinary Anatomy, 11(2):161-7, 1998.

Patten, B. M. \& Carlson, B. M. Foundations of Embryology. $3^{\text {rd }} \mathrm{ed}$. Tata Mcgraw Hill, New Delhi, 1977.
Sisson, S. Ruminant Urogenital system. In Sisson and Grossmans The Anatomy of the Domestic Animals. Ed. Getty, 1975. V. 1. pp. 937-9.

Snedecor, G. W. \& Cochran, W. G. Statistical Methods. Oxford and IBH, Bombay, 1967. pp. 557.

Talukdar, M.; Sarma, M. \& Dev Choudhury, K. Macromorphology of Kidney of One Horned Rhino calf. Indian J. of Animal Sciences, 73(2):184, 2003.

Correspondence to:

Dr. Kamal Sarma. M.V.Sc.

Division of Anatomy \& Histology

Faculty of Veterinary Sciences \& A.H.

S.K. University of Agricultural Sciences \& Technology-Jammu

R.S. Pura, Jammu-181102 ( J. \& K.) INDIA

\section{Email: kamalsarma73@yahoo.com kamalsarma73@gmail.com}

Received: 10-05-2006 Accepted: 27-11-2006 